\title{
IAMJ
}

INTERNATIONAL

AYURVEDIC

MEDICAL JOURNAL

\section{SCOPE OF PANCHAKARMA IN NEURO-DEVELOPMENTAL DISORDERS}

\author{
Achala R. Kumawat ${ }^{1 *}$, Karishma Singh ${ }^{2}$, Gopesh Mangal ${ }^{3}$ \\ ${ }^{1}$ M.D. Scholar, ${ }^{2}$ Ph.D. Scholar, ${ }^{3}$ Associate Professor, \\ Department of Panchakarma, National Institute of Ayurveda, Jaipur, Rajasthan, India
}

Email: drachlaram011@gmail.com

https://doi.org/10.46607/iamj0807212020

(Published online: July 2020)

Open Access

(C) International Ayurvedic Medical Journal, India 2020

Article Received: 23/06/2020 - Peer Reviewed: 04/07/2020 - Accepted for Publication: 07/07/2020

Check for updates

\begin{abstract}
Pediatric neurology has emerged as an important and flourishing super specialty of pediatrics. Burden of neurological disorders in childhood age group is enormous. About a quarter of chronic childhood problems are neurological in origin. Indian subcontinent faces a great burden of neuro-developmental disorders due to dual challenge of genetic and acquired disease burden posed by nutritional, infectious, toxic, and traumatic insults. With a pediatric population that constitutes nearly $40 \%$ of 1200 million people in India, prevalence of neurological disorder in community is estimated as 27.5 per 1000 population in age group 6 months- 2 years. Pursuit for healthy offspring has been mentioned as one of the feats of human life. Not only being childless has been a criticism since ancient times but having a child with congenital or developmental deformities is also a curse. Ayurveda focuses on preventive measures for healthy progeny. Panchakarma helps in improving the quality of progeny. It not only improves the quality of life of child suffering from neurodevelopment disorders, but also relieves the physical, mental, and social stress of the custodian. This paper aims at highlighting the vast scope of therapeutic efficacies of Panchakarma in pediatric neurology.
\end{abstract}

Keywords: Pediatric neurology, Ayurveda, Panchakarma, Neurodevelopmental disorders. 


\section{INTRODUCTION}

Neuro developmental disorders are impairments of the growth and development of the brain or central nervous system. A finer use of the term refers to the disorder of brain function that affects emotion, self-control, learning ability, and memory and that unfolds as the individual grows. A recent study found the prevalence of neurodevelopmental disorders (NDDs) to be nearly $12 \%$ in Indian children aged 2-9 years, providing a muchneeded peek into some of the major health problems faced by the country. ${ }^{1}$ INCLEN study estimated 7.5 $18 \%$ prevalence of neuro-developmental disorders in 29 years age group. ${ }^{2}$ Burden of neurological disorder in childhood age group is enormous; this high magnitude of neurological problem is contributed by high prevalence of neurological disorders like Cerebral Palsy, Epilepsy, Febrile Seizures, Attention deficit hyperactivity disorder (ADHD), Autism, and Mental Retardation etc. In present era, daily visits to pediatricians are greatly influenced by these disorders. Their mounting prevalence in present era demands some productive efforts in this direction. Ayurveda, the Ancient system of medicine not only exemplifies the management of disease but also spots light on precautionary measures to avert their occurrence. Ayurveda is gaining fast popularity for its management of complex neuro-developmental disorders. Present article explores the Panchakarma procedures helpful in the management of neuro-developmental disorders.

\section{Materials}

Ayurveda and modern literature, related research articles, clinical and experimental studies etc.

Neuro-developmental disorders and their management through Panchakarma

\section{Attention deficit/ Hyperactivity disorder (ADHD):}

Attention-deficit/hyperactivity disorder (ADHD) is among the most common neurobehavioral disorders presenting for treatment in children. ${ }^{3}$ ADHD affects an estimated $4 \%$ to $12 \%$ of school-aged children worldwide ${ }^{4}$ with survey and epidemiologically derived data showing that 4 to $5 \%$ of college aged students and adults have ADHD. ${ }^{5}$ The World Health Organization $(\mathrm{WHO})^{6}$ uses a different name-hyperkinetic disorder
(HD). Hyperactivity disorder (HD) is defined by symptoms of inattention, hyperactivity, and impulsivity. Symptoms of inattention include failing to pay close attention to details, appearing to not listen when spoken to directly, becoming easily distracted, and experiencing frequent forgetfulness in daily activities. Symptoms of hyperactivity include being fidgety or restless, running or climbing excessively in inappropriate situations, having difficulty in playing quietly, acting as if "driven by a motor". Symptoms of impulsivity include blurting out answers before a question has been completed, having difficulty awaiting his or her turn, and causing frequent interruptions or intrusions. Prenatal exposure to substances (e.g., nicotine, alcohol) and damage to the central nervous system from trauma or infection increase the risk of HD. The diagnosis is based on strict clinical criteria described in the Diagnostic and statistical manual of Mental Disorders Fourth edition (DSM IV). Stimulants (either methylphenidate or amphetamines) are the first line of treatment in Allopathy. Norepinephrine reuptake inhibitors (atomoxetine and bupropion) are also effective and, along with tricyclic antidepressants, are considered the second line of treatment. Common side effects include appetite suppression and sleep disturbance with stimulant medications, gastrointestinal tract symptoms with atomoxetine, and sedation with alpha agonists (Clonidine and Guanfacine). ${ }^{7}$ Hyperactivity and impulsivity improve with age; however, problems with attention, organization, and planning are usually lifelong disorders. HD may be associated with academic underachievement, difficulties in interpersonal relationships, and poor self-esteem. These can have long-reaching effects (e.g., lower levels of educational, employment attainment). Many adults require continuing pharmacotherapy. Regardless of the name used, ADHD/HD is one of the most thoroughly researched disorders in medicine. ${ }^{8}$ It has been associated with a broad range of negative outcomes for affected subjects and with a serious financial burden to families and society, ${ }^{9}$ which characterizes it as a major public health problem. ${ }^{10}$ In Ayurvedic texts, there is no clear-cut description of any disorder matching that of ADHD. Description of 
abnormal behavior though are found scattered in our texts, they include Anavasthita Chittatva ( mental instability), Manovibhrama (confusion of mind), Buddhivibhrama (confusion state of intellect) etc. The clinical presentation of ADHD when analyzed from Ayurvedic perspective indicates towards Vata Pradoshaja Vikara (diseases due to Vata-Dosha responsible for movement and cognition). As the root seat of pathogenesis is higher centers, in such cases Shiroabhyanga ( Head massage), Shirodhara ( $\sim$ streaming of medicated liquid over forehead), Shiropichu ( keeping sterile cotton pad dipped in medicated oil over bregma), Shirobasti ( retention of medicated liquid overhead), Abhyanga ( Therapeutic massage), Basti ( Therapeutic enema) and Nasya ( Errhine therapy) may prove to be useful. ${ }^{11}$ Oleating the body helps in pacification of Vata which is responsible for hyperactive behavior in ADHD patients. So, using Oil in the form of Abhyanga, Dhara, Pichu and Shirobasti may be helpful in the children with ADHD; moreover, Sparsha Chikitsa ( Tactile stimulation therapy) has its own role in healing the patient. Basti has been referred to as the prime treatment modality for pacification of vitiated Vata, so Matra Basti ( Therapeutic oil enema) with Vatanashaka Taila ( Oil to alleviate Vata) also may be beneficial in such cases. Moreover, Basti by its potency draws morbid Doshas located in the entire body, right from the foot to head and expels them out through the lower gut ${ }^{12}$. Nasya is a therapeutic measure where the medicated oil or drugs are administered through nose to eliminate the vitiated Doshas situated in Sira. Though Nasya is indicated after 8 years of age, Pratimarsha Nasya can be given at any age. As per a research work by Cowley et. al. (1975), certain drugs administered through nose may have an impact on immediate psychological functions by acting on limbic system through olfactory nerves.

\section{Cerebral Palsy:}

Cerebral palsy (CP) is a non-progressive disorder of tone and posture that results from an acquired prenatal and postnatal insult that is not the result of an obvious congenital abnormality. Nearly $15-20 \%$ of the total physically handicapped children suffer from Cerebral Palsy (CP). For India, the estimated incidence is around 3/1000 live births; however, being a developing country, the expected actual figure may be much higher. ${ }^{13}$ Despite the advancement in modern technology and improved neonatal care, stagnant or increasing incidence of CP has been observed, which is of great concern. Numerous perinatal risk factors have been linked to $\mathrm{CP}$, including prematurity, congenital infections such as toxoplasmosis, other infections, Rubella, Cytomegalovirus and Herpes simplex (TORCH), trauma, neonatal infections etc. High levels of cytokines in blood of term infants who develop quadriparetic spastic $\mathrm{CP}$ suggest that maternal inflammation (Chorioamnionitis) plays a role in such cases. Neonatal examination is not predictive of $\mathrm{CP}$; findings of $\mathrm{CP}$ become apparent during first two years of life. Management of children with $\mathrm{CP}$ requires a multidisciplinary approach. The treatment of spasticity should be individualized and can respond to physiotherapy, anti-spasmodic agents, orthopedic or neurosurgery. Spasticity often worsens over time. CP is often associated with mental retardation, but severe motor deficits may be associated with normal intelligence.

Cerebral Palsy cannot be correlated with any single disease or condition, as it is a multi-factorial disease with clinical features of wide variation. As per contribution of the causative factor the disease phenomenon comes under the broad heading of Aadibala (Hereditary anomalies), Janmabala (Congenital anomalies) and Doshabala (Diseases caused by Vitiated Dosha) Pravrit Vyadhi. However, considering the classification and individual features of Cerebral Palsy, it can be taken as condition closer to Vata Vyadhi or Vata Vikara or Vata predominant condition.

A Comparison of Classification of Cerebral Palsy and Vata Vikara can be made: 
Table1: Comparison of classification of Cerebral Palsy and Vata Vikara:

\begin{tabular}{|c|c|c|}
\hline Classification & & Vata Vikara \\
\hline Hypotonic CP & & Saada \\
\hline Spastic type; & $\begin{array}{l}\text { Monoplegia } \\
\text { Hemiplegia } \\
\text { Quadriplegia } \\
\text { Diplegia }\end{array}$ & $\begin{array}{l}\text { Ekangavadha } \\
\text { Pakshavadha } \\
\text { Sarvanga Roga } \\
\text { Pangu }\end{array}$ \\
\hline Ataxic, Athet & c type & Cheshtavriddhi, Chalatva \\
\hline
\end{tabular}

Although children are presumed to be Sukumara and contraindications for Panchakarma therapy, but Panchakarma proves to be advantageous in neuro developmental disorders like CP. Although there is no promising treatment of $\mathrm{CP}$ in any system of medicine, but still Panchakarma can enhance the quality of life of CP patients, nailing its worth in today's era of neurodevelopmental suffering. Therapies like Abhyanga with Vatanashaka and Balya Sneha, Shashtika Shali Pinda Sweda, Basti, Shirodhara, Shirobasti, etc. may prove to be beneficial.

\section{Autism Spectrum Disorders:}

Autism spectrum disorders (ASDs) are a group of child-development disabilities defined by substantial social, interaction, and behavioral impairments. Autism is stated to be a "developmental disorder" as the symptoms generally appear in the first two years of life. The term "spectrum disorders" refers to the fact that although people with ASDs share some common symptoms, ASDs affect different children in different ways, with some experiencing very mild symptoms and others experiencing severe symptoms. There are multiple causes of ASD, although most are not yet known, research suggests that genes can act together with influences from the environment to affect development in ways that lead to ASD. Children with ASDs may show lack of interest in other people, have trouble showing or talking about feelings, and usually resist physical contact. As an infant there is delayed or absent social smiling. Speech often is delayed and, when present, it is frequently dominated by echolalia (meaningless repetition of words). Another hallmark characteristic of ASDs is the demonstration of restrictive or repetitive interests or behaviors, such as lining up toys, flapping hands, rocking his or her body, or spinning in circles. ${ }^{14}$ Common comorbidities are mental retardation (in up to
$80 \%$ ), seizure disorder (in 25\%), anxiety disorders, OCD, and attention-deficit/hyperactivity disorder. Seizures often start around the onset of puberty. The earliest studies of autism suggested a relatively poor prognosis, with only a small number of individuals ( $1 \%$ to $2 \%$ ) being able to function independently as adults. Recent research reveals major gains, but not a cure, with early diagnosis and treatment. ${ }^{15}$

The clinical presentation of ASD when analyzed from Ayurvedic perspective indicates towards Vata Nanatmaja Vikara (Diseases occurring due to only Vitiated Vata). Mookatva (muteness/dumbness or aphasia), Ashabdshravana Badhirya (deafness or hearing impairment), Anavasthitchittatva (mental instability) and Satata Gati (continuous movement) are few of the Vata Nanatmaja Vikara which find resemblance to the features of Autism. ${ }^{16}$ Vata Dosha is a prime factor responsible for the neurological as well as physiological functions of the body. Dushti (Vitiation) of Vata is the most important reason in developing the features of autism. Acharya Charaka also mentions that this Dushta Vayu (Vitiated Vayu) can destroy the senses (Shrotraadishu Indriyavadham Kuryaadoushtsameeranah). ${ }^{17}$ To win over this Kupita Vayu (Vitiated Vayu), there is nothing better than Basti. Matra Basti can be administered in such cases. Taila (Oil) is deputed to be Param Vatahara ( best to alleviate Vata). And this Vatashamana can be achieved by Snehana Nasya, Shirobasti, Shirodhara and Abhyanga.

\section{Childhood Absence Epilepsy (CAE):}

CAE accounts for 1 to 4 out of 50 people with epilepsy ( 2 to $8 \%$ ). Absence seizures usually begin between the ages of 4 and 8 years old ${ }^{18}$ and usually resolve by late childhood or adolescence. If absence does not remit, $44 \%$ will go on to develop juvenile myoclonic epilepsy. ${ }^{19}$ Ethosuximide is the first-choice therapy. A 
subset of patients also has generalized tonic-clonic seizures. For these children, valproic acid is the first choice as it can prevent both absence and convulsive seizures. Comorbid learning disabilities and ADHD are common.

\section{Juvenile Myoclonic Epilepsy (JME)}

JME is a common epilepsy syndrome, comprising an estimated $5-10 \%$ of all the epilepsies. ${ }^{20}$ Onset is usually in adolescence, between 13 and 18 years of age. The cardinal seizure type is a myoclonic seizure, usually involving the arms and shoulders symmetrically and preferentially occurring in early morning. Valproic acid, lamotrigine, or topiramate are the first line medications, although there are reports that seizures may not be completely controlled with lamotrigine. In contrast to CAE patients, those with JME generally do not have remission of their seizures and require anticonvulsant treatment throughout their lives. ${ }^{21}$

Apasmara (Epilepsy) is defined as Vibhatsacheshta (Sudden abhorrent bodily activities) accompanied by Tamahpravesha (momentary blackouts or loss of consciousness) owing to disturbances in mental faculties of Dhi (intelligence), Dhriti (retention) and Smriti (memory). ${ }^{22}$ In such cases, Panchakarma therapies like Virechana (Therapeutic purgation), Nasya can provide effective results. Virechana does Vatanulomana (proper elimination of flatus, feces, urine etc./ proper functioning of Vayu), Pitta Rechana ( purgation of Vitiated Pitta) and elimination of vitiated Kapha Dosha.

${ }^{23}$ Virechana is indicated after 16 years of age. Nasya can be effective in such conditions as it eliminates the Dosha from Sira, which is the seat of pathology. Moreover, when Nasya is performed using Gomutra ${ }^{24}$ (Cow's urine), it is found to be valuable in increasing the Vegantara Kala (the time duration between two epileptic seizures).

Epilepsy can also be linked with Skandapasmara Balagraha in Ayurveda (alternate unconsciousness and consciousness, hyperactive movements of hands and feet, yawns and emits froth). ${ }^{25}$ Its management involves Abhyanga, Parisheka (Therapeutic streaming), Utsadana (therapeutic powder-oil mixture massage) with Vacha (Acorus calamus) and Hingu (Ferula asafetida) as mentioned in classics. ${ }^{26}$

\section{DISCUSSION}

As Neuro-developmental disorders ensue due to impairment in the growth and development of brain, measures can be implemented to prevent such happening. Preconceptional Shodhana (Purification) is one of such measures. The benefit of Virechana has been referred to as "Beejakarmukatvam"27 i.e. it improves the quality of Beeja (male and female gametes), thus helping in Healthy Progeny. Though genetic factors also seem to play a role and may be to avoid these kind of genetic disorders, Acharya Charaka has prohibited consanguineous marriage, citing it as one of the prime causes for developing genetic and congenital disorders. ${ }^{28}$ As these neuro developmental disorders are a result of prenatal and perinatal insults, antenatal and postnatal management as advised in classics should be followed. Every physiological and psychological variation in the mother exerts its influence on the growing fetus. The pregnant woman must obey various norms of health to keep herself and the fetus healthy. The $J a$ takarma mentioned in the Paricharya of Navajata ${ }^{29}$ (various procedures done for the baby soon after birth) should be followed as they promote intellect, longevity, and strength of the child. Bala Paricharya ( regimens for child), various Prasha and Medhya Rasayana (intellect enhancer) mentioned in the classics should be used for a healthy childhood devoid of any sufferings. Sattvavajaya Chikitsa or counseling of the parents, family members, teachers, and child itself may also prove to be beneficial in the management of these disorders. Once the disorder has developed, no therapy promises reversal of the pathology or complete recovery. Yet, Panchakarma carries a ray of hope; not only it can improve the quality of life of the child and custodian but may be useful in gifting the sufferers a better health. Panchakarma therapies like Basti, Nasya, Shirodhara, Abhyanga, Shashtika Shali Pinda Sweda have their role in neuro-developmental disorders. Brimhana Nasya can be used effectively due to its direct effect on the Indriya ( $\sim$ Senses). Nasya has proven effects at Neuropsychological levels. ${ }^{30}$

Abhyanga is a process by which the body surface undergoes manual pressure by various techniques and various substances to provide not only relaxation to the 
body but to pacify several types of diseases. Skin is the gateway of the body through which Abhyanga may act on different systems of body. Absorption of drug mainly occurs through first (Udakdhara) and second (Asrigdhara) layers of Skin. The oil used in Abhyanga reaches up to $6^{\text {th }}$ layer (Majja) in 900 Matra Kala (285 seconds). This layer mainly contains the nerve fibers which by Abhyanga gets nourishment to combat diseases occurring due to Vata. ${ }^{31}$ Abhyanga increases blood supply to the area of application. It is recorded that amount of amino acids like tryptophan fairly increases in blood after performing a lymphatic massage. This increased level of tryptophan in plasma may cause an increase in the level of several neurotransmitters and serotonin that helps an individual to fight anxiety, depression and many more. Abhyanga may influence the emotional status of an individual by tactile stimulation. Twak or Sparshnendriya is the seat of Vata, and Abhyanga with oil alleviates the vitiated Vata. A slow rhythmic Samvahana with light stroke can induce tranquility. Anuloma Gati (movement towards caudal direction) in neck and back is very much beneficial for the nervous system. ${ }^{32}$ Thus, this therapy might prove beneficial in neurodevelopment disorders not only by controlling Vata to perform its physiological functions, but by stimulating Nervous system also. In pathological conditions involving tight and restricted state of fascia, the myofascial release techniques like gentle massage, deep pressure and tactile stimulation restores the normal status of fascia and imparts flexibility to stretch and move without undue restriction.

Shiroabhyanga nourishes the Indriya. ${ }^{33}$ It helps to overcome anxiety, stress as well as mental fatigue.

Shashtik Shali Pinda Sweda (SSPS) is a type of sudation procedure, performed by boluses of Shashtik Shali (Oryza sativa Linn.) cooked with Balamoola Kwatha (decoction of Sida cordifolia Linn.) and milk. ${ }^{34}$ SSPS may improve the blood circulation (due to heat), relieve muscle spasm, and increase tendon extensibility. ${ }^{35}$ Thus, it may help in reduction of spasticity and facilitate free movement of joints and may especially be beneficial in cases of spastic Cerebral palsy. Shashtik Shali possess Snigdha, Guru and Sthira properties, these Guna are opposite to that of Vata, and thus may be helpful in pacifying Vata. Moreover, Shashtik Shali, Bala and Godugdha are Balya in nature, thus may provide strength to the body.

Basti is a prime treatment modality for Vata Dosha. There is no treatment equivalent to Basti in the protection of Marma and in the management of their afflation which are considered as vital parts in body. ${ }^{36}$ It stabilizes the $A y u$ ( age), and normal functions of Dosha (regulatory functional factors of the body) and Dhatu (major structural components of the body). It may act through neuronal stimulation via Enteric nervous system (ENS). ENS or Gut brain is an integrative system with structural and functional properties like those in Central Nervous system. It lies entirely in the wall of the gut (Mesenteric and Myenteric plexuses), containing approximately 100 million neurons exactly equal to the number in the entire spinal cord. This makes the role of Basti in neurological disorders very clear. Basti reaches up to Grahani. Grahani possess Pittadhara Kala. As per Acharya Dalhana Pittadhara Kala and Majjadhara Kala are same. Thus, it can be interpreted that Basti reaches up to Majja. Moreover, being the best pacifier of Vata, it normalizes the functioning of Vayu. Thus, the role of Basti in neurodevelopmental disorders cannot be neglected.

Nasya Karma is a means of delivering drugs preferentially to the brain. Olfactory nerves arise from a specialized olfactory epithelium in the olfactory mucosa and ascend through the cribriform plate to reach the olfactory bulb which lie inferior to frontal lobes. Axons of olfactory bulb neurons extend posteriorly and form olfactory tract which projects into a region called lateral of olfactory area which is located at inferior and medial surface of the temporal lobe. The olfactory nerves relate to the higher centers of brain i.e. limbic system, consisting mainly of amygdaloidal complex, hypothalamus ganglia etc. The limbic system is concerned with multifunctional capabilities including behavioral aspect of human beings. So, the drugs administered through nose may stimulate the higher centers of brain which might regulate the nervous system functions and may prove to be beneficial in neurobehavioral disorders. ${ }^{37}$ 
Shirodhara induces a relaxant state. These calming effects are mediated by the brain wave coherence, $\alpha$ waves, and a down regulation of the sympathetic outflow. The midpoint of the forehead is known as Agya Chakra. Focusing on Agya Chakra during meditation with closed eyes leads to psychosomatic harmony. As the oil drips on the Agya Chakra, it is proposed that the meditation-like effect is a consequence of tranquility of mind leading to adaptive response to the basal stress. Research study confirms a stress-relieving effect as judged by the mean score on V.A.S., EEG changes, and vital signs. ${ }^{38}$

\section{CONCLUSION}

Being childless is the major curse, any couple can suffer. But having a child with neurological disorder is also miserable. Thus, every effort should be made to raise awareness about these disorders and their prevention through Preconceptional Shodhana. The cure of these neurodevelopmental diseases can be achieved through Panchakarma in the form of Abhyanga, Shiroabhyanga, Shashtik Shali Pinda Swedana, Shirodhara, Shirobasti, Basti and Nasya.

\section{REFERENCES}

1. https://indiabioscience.org/news/2018/neurodevelopmental-disorders-in-india-may-affect-as-many-as-12 [ Last accessed June 2020, 23]

2. Juneja M, Mishra D, Rusell PS, Gulati S et al. INCLEN Diagnostic tool for Autism Spectrum Disorder (INDTASD): Development and Validation. Indian pediatrics. 2014; 51(5): 359-65.

3. Clinical practice guideline: treatment of the school-aged child with attention-deficit/hyperactivity disorder. Pediatrics. 2001 Oct;108(4):1033-1044. [PubMed] [Google Scholar]

4. Polanczyk G, de Lima MS, Horta BL, Biederman J, Rohde LA. The worldwide prevalence of ADHD: a systematic review and metaregression analysis. The American Journal of Psychiatry. 2007 Jun;164(6):942-948. [PubMed] [Google Scholar]

5. Kessler RC, Adler L, Barkley R, et al. The prevalence and correlates of adult ADHD in the United States: Results from the national comorbidity survey replication. American Journal of Psychiatry. 2006;163(4):716-723. [PMC free article] [PubMed] [Google Scholar]
6. World Health Organization: The ICD-10 Classification of Mental and Behavioral Disorders: Diagnostic Criteria for Research. Geneva, Switzerland, World Health Organization, 1993Google Scholar

7. Sheila Gahagan, Yi Hui Liu, Scott. J. Brown. Behavioural disorders. Nelson essential of paediatrics. 7th edition, Elsevier Saunders publishers. 2015. USA, Chapter 13. P. 41

8. Goldman LS, Genel M, Bezman RJ, Slanetz PJ: Diagnosis and treatment of attention-deficit/hyperactivity disorder in children and adolescents: Council on Scientific Affairs, American Medical Association. JAMA 1998; 279:1100-1107Google Scholar

9. National Institutes of Health: National Institutes of Health Consensus Development Conference Statement: diagnosis and treatment of attention-deficit/hyperactivity disorder (ADHD). J Am Acad Child Adolesc Psychiatry 2000; 39:182-193Google Scholar

10. Lesesne C, Abramowitz A, Perou R, Brann E: Attention Deficit/Hyperactivity Disorder: A Public Health Research Agenda. http://www.cdc.gov/ncbddd/adhd/dadphra.htm, 2000 (Accessed Aug. 2006)Google Scholar

11. Bohra Mohita, Sharma Parul, Sharma Ved Bhushan. Management of Attention Deficit Hyperactivity Disorder (ADHD) Through Panchakarma. Int.J. Res. Ayurveda Pharm. 2015; 6(6).

12. Shastri RD, editor. Charaka Samhita of Agnivesha. Reprint 2009.Varanasi: Chaukhamba Bharati Academy, 2009. Siddhisthana, Chapter 7, Verse 64. p. 1042.

13. Vyas, A. G., Kori, V. K., Rajagopala, S., \& Patel, K. S. (2013). Etiopathological study on cerebral palsy and its management by Shashtika Shali Pinda Sweda and Samvardhana Ghrita. Ayu, 34(1), 56-62. https://doi.org/10.4103/0974-8520.115450

14. https://www.cdc.gov/ncbddd/autism/signs.html [Last Accessed June 2020, 23]

15. Russell Scheffer, Aveekshit Tripathi. Psychiatric disorders. Nelson essential of paediatrics. 7th edition, Elsevier Saunders publishers. 2015. USA, Section 4; Chapter 20. P. 64.

16. Shastri RD, editor. Charaka Samhita of Agnivesha. Reprint 2008.Varanasi: Chaukhamba Bharati Academy, 2008. Sutrasthana, Chapter 20, Verse 11. p. 399.

17. Shastri RD, editor. Charaka Samhita of Agnivesha. Reprint 2009.Varanasi: Chaukhamba Bharati Academy, 2009. Chikitsasthana, Chapter 28, Verse 29. p. 782. 
18. https://www.epilepsy.com/learn/types-epilepsy-syndromes/childhood-absence-epilepsy [ Last Accessed June 2020, 23]

19. Schiller JH, Shelhaas RA. Neurology. Nelson essential of paediatrics. 7th edition, Elsevier Saunders publishers. 2015. USA, Section 24; Chapter 181. P. 621.

20. Carol S Camfield, Pasquale Striano, Peter R Camfield. Epidemiology of Juvenile Myoclonic Epilepsy. Epilepsy and Behavior. 2013 Jul;28 Suppl 1: S15-7. doi: 10.1016/j.yebeh.2012.06.024. https://www.ncbi.nlm.nih.gov/pubmed/23756473

21. Shih Tina. Epilepsy and Seizures. In: John C M Brust, editor. Current Diagnosis and treatment. USA: Mc Graw Hill Publications; 2007. p. 53

22. Shastri RD, editor. Charaka Samhita of Agnivesha. Reprint 2009.Varanasi: Chaukhamba Bharati Academy, 2009. Chikitsasthana, Chapter 10, Verse 3. p. 328.

23. Chitrangana Cn et.al. Explorative Study on efficacy of Ayurvedic therapy and an Ayurvedic compound preparation in the management of Epilepsy. International Journal of Research in Ayurveda and Pharmacy. 5 (6). 10.7897/2277-4343.056142.

24. Shastri RD, editor. Charaka Samhita of Agnivesha. Reprint 2015.Varanasi: Chaukhamba Bharati Academy, 2015. Chikitsasthana, Chapter 10, Verse 41. p. 335.

25. Shastri AD, editor. Sushruta Samhita of Sushruta. Reprint 2011.Varanasi: Chaukhamba Sanskrit Sansthan, 2011. Uttaratantra, Chapter 27, Verse 9. p. 184.

26. Shastri AD, editor. Sushruta Samhita of Sushruta. Reprint 2011.Varanasi: Chaukhamba Sanskrit Sansthan, 2011. Uttaratantra, Chapter 28, Verse 3-5. p. 187-8.

27. Kashyapa Samhita of Vriddha Jeevaka. Reprint 2015.Varanasi: Chaukhamba Sanskrit Sansthan, 2015. Siddhisthana, Chapter 2. p. 225.

28. Shastri RD, editor. Charaka Samhita of Agnivesha. Reprint 2008.Varanasi: Chaukhamba Bharati Academy, 2008. Shareera Sthana, Chapter 2, Verse 3-4. p. 837.

29. Shastri RD, editor. Charaka Samhita of Agnivesha. Reprint 2013.Varanasi: Chaukhamba Bharati Academy, 2013. Sharirasthana, Chapter 8, Verse 11. p. 950.

30. Vasant $C$ Patil. Principles and practices of Panchakarma. 4th edition. New Delhi: Chaukhamba Publications. 2014. Chapter 14. p.533.

31. Pulak Kanti Kar. Mechanism of Panchakarma and its module of investigations. 1st edition. New Delhi: Chaukhamba Sanskrit Pratishthan. 2013. Chapter 1. p. 27.

32. Pulak Kanti Kar. Mechanism of Panchakarma and its module of investigations. 1st edition. New Delhi: Chaukhamba Sanskrit Pratishthan. 2013. Chapter 1. p. 32.
33. Shastri AD, editor. Sushruta Samhita of Sushruta. Reprint 2010.Varanasi: Chaukhamba Sanskrit Sansthan, 2010. Chikitsasthana, Chapter 24, Verse 25-26. p. 133.

34. Lohith B A. A Textbook of Panchakarma. 1st edition. Varanasi: Chaukhamba Orientalia. 2016. Chapter 3.p. 145.

35. Gupta Kshama, Mamidi Prasad. Efficacious ayurvedic panchakarma procedures in children with cerebral palsy. International journal of complementary and alternative medicine. 2018; 11(1):3-42. DOI: 10.15406/ijcam.2018.11.00344

36. Shastri RD, editor. Charaka Samhita of Agnivesha. Reprint 2009.Varanasi: Chaukhamba Bharati Academy, 2009. Siddhisthana, Chapter 9, Verse 7. p. 1053.

37. Ramteke Rajkala S. Patil Panchakshiri D, Thakar Anup B. Efficacy of Nasya (nasal medication) in coma: A Case Study. Anc Sci Life. 2016; 35(4): 232-235.

38. Dhuri KD, Bodhe PV, Vaidya AB. Shirodhara: A psycho-physiological profile in healthy volunteers. $J$ Ayurveda Integr Med. 2013;4(1):40-44. doi:10.4103/09759476.109550 .

\section{Source of Support: Nil \\ Conflict of Interest: None Declared}

How to cite this URL: Achala R. Kumawat et al: Scope Of Panchakarma In Neuro-Developmental Disorders. International Ayurvedic Medical Journal \{online\} 2020 \{cited July, 2020\} Available from: http://www.iamj.in/posts/images/upload/3951 3958.pdf 